Annals of Warsaw University of Life Sciences - SGGW

Land Reclamation No 49 (2), 2017: 95-106

(Ann. Warsaw Univ. of Life Sci. - SGGW, Land Reclam. 49 (2), 2017)

\title{
The usefulness of low-altitude aerial photography for the assessment of channel morphodynamics of a lowland river
}

\author{
PIOTR OSTROWSKI ${ }^{1}$, TOMASZ FALKOWSKI ${ }^{1}$, DARIUSZ KARCZMARZ ${ }^{2}$, \\ PRZEMYSŁAW MĄDRZYCKI ${ }^{2}$, HENRYK SZKUDLARZ ${ }^{2}$ \\ ${ }^{1}$ Faculty of Civil and Environmental Engineering, Warsaw University of Life Sciences - SGGW \\ ${ }^{2}$ Division for Aeronautical Training Systems \& Air Force Command \& Control, Air Force Institute \\ of Technology
}

\begin{abstract}
The usefulness of low-altitude aerial photography for the assessment of channel morphodynamics of a lowland river. The paper presents examples of using low-altitude aerial images of a modern river channel, acquired from an ultralight aircraft. The images have been taken for two sections of the Vistula river: in the Małopolska Gorge and near Dęblin and Gołąb. Alongside with research flights, there were also terrestrial investigations, such as echo sounding of the riverbed and geological mapping, carried out in the river channel zone. A comparison of the results of aerial and terrestrial research revealed high clarity of the images, allowing for precise identification of the evidence that indicates the specific course of river channel processes. Aerial images taken from ultralight aircrafts can significantly increase the accuracy of geological surveys of river channel zones in the Polish Lowlands due to low logistic requirements.
\end{abstract}

Key words: remote sensing, channel processes, low-altitude aerial photography

\section{INTRODUCTION}

The increase in flood flow rates observed in recent years has raised the interest of researchers in the fluvial environment and the processes in river valleys. Failures of flood protection structures and related material damages also increased the need to identify the causes of such events and to develop effective preven- tive measures. Apart from analysing the probability of the occurrence of extreme events in river channels, it is important for flood prevention to define correctly the conditions of foundation of hydrotechnical structures. In addition to the soil profile characteristics, it is also necessary to provide an analysis of channel/channel zone dynamics under different flow conditions.

Remote sensing techniques have long been an effective way of both identifying the nature of river processes and determining the directions of their evolution. The beginnings of such research in Poland date back to the 1930s, and its peak development took place in the 1970s (Falkowski 1971, Kozarski and Rotnicki 1977, Szumański 1986). Interest in the use of aerial imagery in environmental research was most likely a result of the experiences of World War II, when aerial photography became an unexpectedly important method of identifying the area of combat activities, including determining the conditions for crossing rivers.

Aerial and satellite imagery of river valleys allows for the identification of relief features and for the determination of the boundaries of outcrops of surface deposits. This is possible due to both the 
phototonal variations seen in the images and the characteristics of the structure and texture of the remote sensing image. They also often allow for the assessment of the depth to the groundwater table in lithologically homogeneous geomorphologic landforms such as the fluvial plains.

Currently, many remote sensing techniques are used to study river valleys. Among the most important ones are high-resolution, multi-spectral satellite images, digital aerial photographs, and remote laser scanning (Kurczyński 1999, Kaczyński and Ewiak 2006, Thorndycraft et al. 2008, Ostrowski and Falkowski 2015). The disadvantage of these methods is the need to use technologically advanced equipment, and a very high cost of imaging operations. These factors significantly limit the possibility of obtaining materials with high temporal resolution. In the case of research conducted for hydrotechnical constructions, spatial planning, or environmental protection, the high temporal resolution is a key parameter to identify changes of the river channel morphology in the changing flow conditions. The high temporal resolution, and therefore the imaging of the dynamics of environmental changes in the valley bottom, can be provided by the use of aircrafts for aerial photography, which do not require expansive and expensive logistics facilities. These are ultralight aircrafts and unmanned aerial vehicles (UAV) (Feurer et al. 2008, Witek et al. 2013). They allow taking images from low altitudes. This, even when using small-format non-metric cameras, enables acquiring high-resolution spatial data (Bakuła and Ostrowski 2012).

The main objective of the study was to determine the usefulness of aerial pho- tographs taken from low altitudes using a non-metric digital camera to identify selected morphodynamic elements of a part of the channel of a lowland river. Remote sensing materials acquired from an ultralight aircraft of class LSA (Light Sport Aircraft) were supplemented by hydrographic, geological and geomorphological studies. The work was performed by a research team composed of specialists from the Department of Geotechnical Engineering of Warsaw University of Life Sciences - SGGW and the Air Force Institute of Technology.

\section{STUDY AREA}

The aim of the study was an attempt to analyse the channel morphodynamics typical of large rivers in the Polish Lowlands. The study was conducted within two sections of the middle Vistula river, named hereafter the Solec and Gołąb sections (Fig. 1). The specificity of the course of modern river channel processes in these sections results from differences in the geological structure of the valley. The Solec section is located within the Małopolska Gorge of the Vistula. The detailed study covered a $10-\mathrm{km}$ section of the channel from near Solec nad Wisła (km 330) to the confluence with the Iłżanka river ( $\mathrm{km} 340)$. In this section, the Vistula valley is incised into Upper Cretaceous solid rocks represented by limestones, marls, opokas and chalk (Pożaryski et al. 1994). The second section of Gołąb, which shows a full lowland river character, covered a $16-\mathrm{km}$ long part of the river channel from Gołąb (km 379) to Dęblin ( $\mathrm{km} \mathrm{395).}$ The bedrock in the river valley is represented by Paleogene deposits: these are 


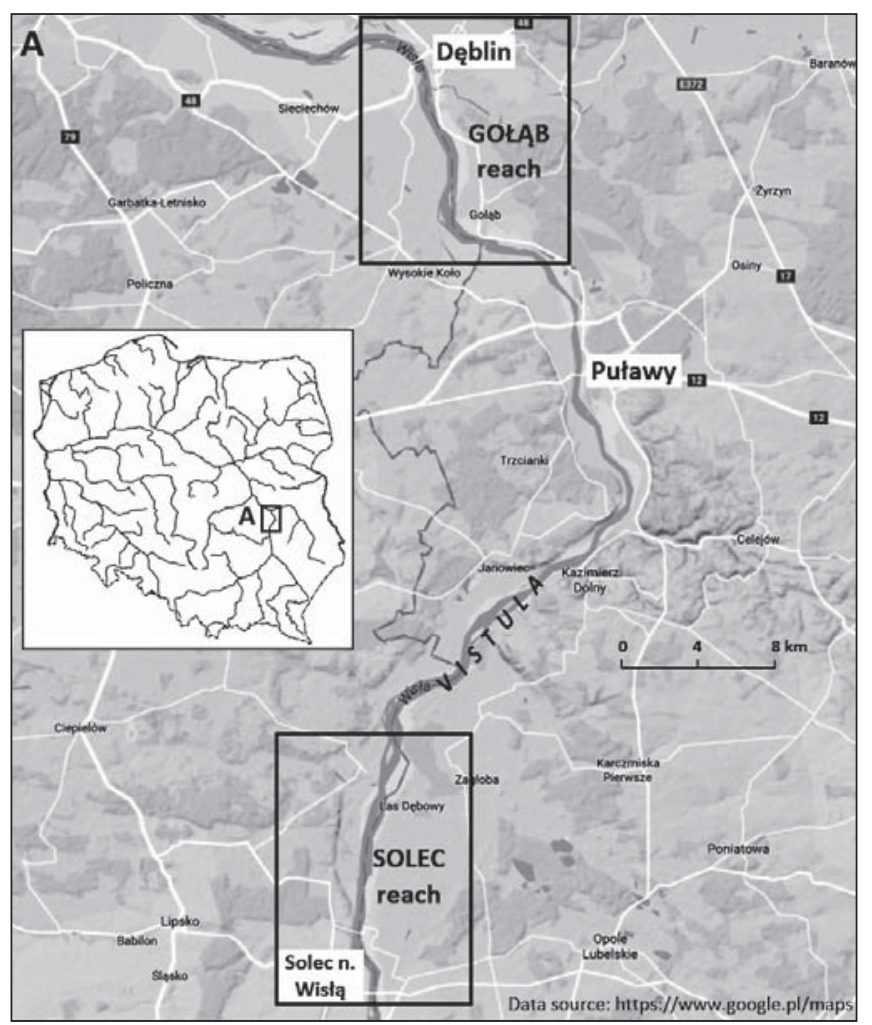

FIGURE 1. Location of the study reaches

gaizes, limestones and marls in the vicinity of Gołąb, and muds and clays in the Dęblin environs (Żarski 1993).

The Vistula is a braided river in both these sections (Starkel 2001). The degree of river engineering is estimated by the administrator of the middle Vistula river at ca. $80 \%$. Most of the hydraulic structures have been degraded here (RZGW Warszawa 2017).

\section{MATERIAL AND METHODS}

Essential fieldwork was done using two mutually complementary components: an ultralight aircraft equipped with a digital non-metric camera, and a hydrographic set consisting of an echo sounder integrated with the DGPS receiver.

The aviation component was the "Flying Laboratory" of the Air Force Institute of Technology (Perz-Osowska et al. 2011, Szkudlarz 2014a). That has been built on the base of Sonex aircraft, manufactured by Sonex Aircraft, LLC in Oshkosh, WI, USA. The standard version of aircraft had been converted and adapted for the needs of research by wings structure reinforcement and three outer hangers installation: two under the wings and the third under the fuselage (Szkudlarz 2014b). The aircraft was also equipped with "glass cockpit" avionic, which is based on Garmin systems, consisting of, among others EFIS G600 and 
GNS 530 navigation system. A container with Sony EC75000 digital non-metric camera was placed in outer hanger, under the fuselage (Fig. 2). A radio transmitter along with the remote sensing measuring system had been installed on the plane. Data obtained during the measurements were transmitted in real-time from the aircraft board to the ground research station. A constant contact between the aircraft crew and the ground research station staff was maintained.

Vistula channel zone images were taken from $300 \mathrm{~m}$ height while the average cruising speed was $180 \mathrm{~km} / \mathrm{h}$. Due to the low flight ceiling and the width of Vistula channel, a series of pictures needed to be taken. In Solec region, three flights had been carried out, and in Gołą - four. Spacing between plane paths were 160 -180 and $180-200 \mathrm{~m}$, respectively.
The hydrographic measuring system used in the study consisted of two basic components: an EA 400SP echo sounder from Konsberg, and a DGPS Magellan FX324 Map Color receiver supported by the EGNOS (European Geostationary Navigation Overlay Service) system. The echo sounder, equipped with active digital transducers, generated simultaneous dual-frequency pulses of 38 and $200 \mathrm{KHz}$. The pulse speed was $1,470 \mathrm{~m} / \mathrm{s}$ and the beam width was $13^{\circ}$. The minimum depth of the river channel for obtaining a reliable measurement was $0.5 \mathrm{~m}$. The hydrographic measuring system was installed on a 4.2-m long light pontoon, as there was a very low water level in the river channel.

An important objective of these surveys was the collection of data from both of the research platforms simultaneously

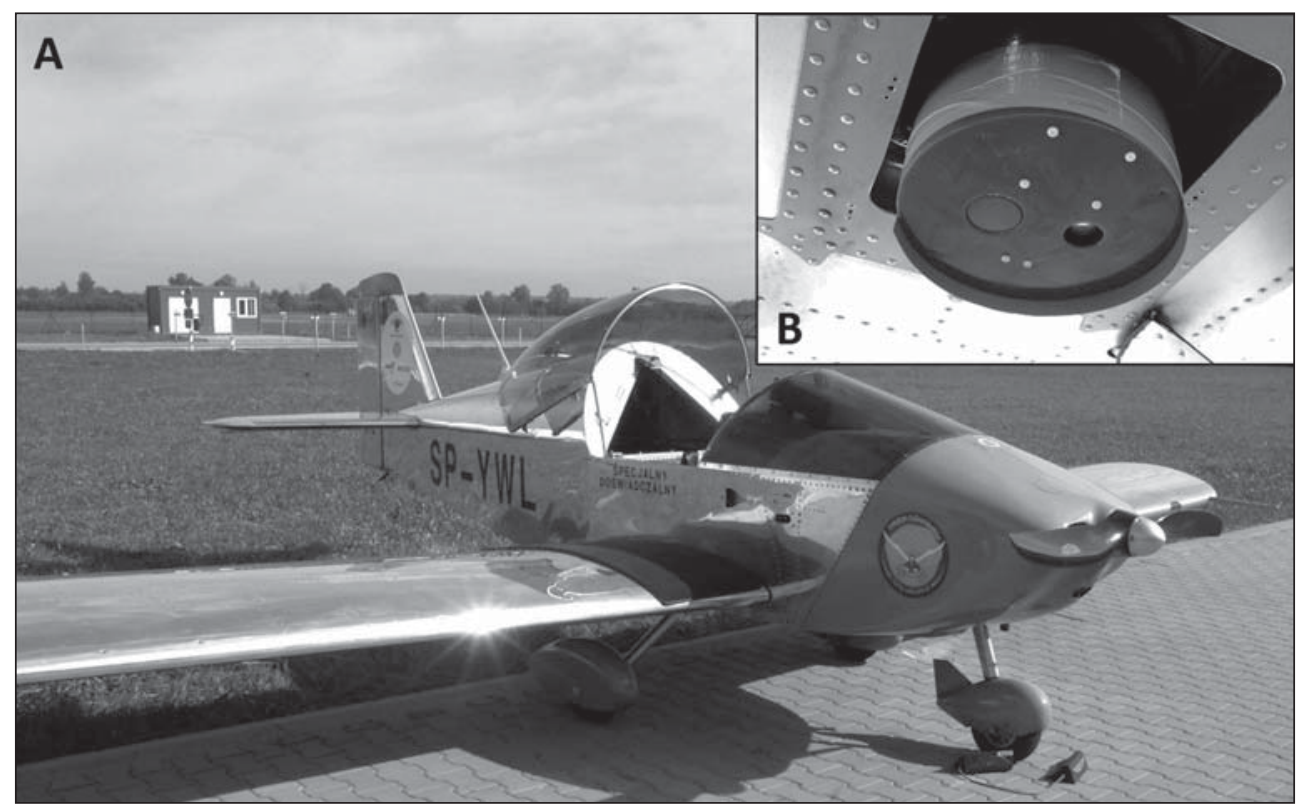

FIGURE 2. Modernized aircraft LSA class (A) and container with photo camera on the hanger under the fuselage (B) 
(in the same hydrological situation), and their further joint analysis. The research flights took place on September 3, 2016. Bathymetric measurements in the Gołąb section were made on September 3-4, 2016, and in the Solec section - on September 5, 2016. During the surveys, very low water-level and flow-rate values were observed in the entire middle Vistula river course (Table), which significantly hampered the bathymetric measurements. Therefore, the echo sounding was carried out only in accessible parts of the river channel (within and close to the main river current). The remaining zones were examined by geological mapping.

The source material for the remote sensing analysis was a natural colour film recorded with a non-metric HD digital camera. The first stage of in-house work was an overview of the film material and the selection of film frames in which the image of the Vistula river channel zone was recorded. For particularly interesting sections, it was decided to make a photographic mosaic of 4 to 12 frames. For this purpose, the individual frames were merged, then subjected to the image aggregation process, and finally saved as TIF files. These files were entered into a GIS database and calibrated based on permanent elements occurring in the Vistula river channel zone. In the case of the recorded materials, a $0.15-\mathrm{m}$ spatial resolution was obtained.

Emerged and submerged channel forms, the course of the main river current, and the components of hydrotechnical structures or their remnants in the channel were mainly identified during the remote sensing surveys. The surveys also included an attempt to evaluate the depth of the river channel, based on both the variation in the phototone of the remote sensing image and the results of simultaneous bathymetric measurements.

TABLE. Water levels and flow rates in the Vistula river channel at some gauge stations during fieldwork, presented against the data for the multi-annual period 1958-2010

\begin{tabular}{|c|c|c|c|c|c|c|c|}
\hline \multirow{2}{*}{\multicolumn{2}{|c|}{$\begin{array}{l}\text { Date of bathymetric } \\
\text { measurement }\end{array}$}} & \multicolumn{2}{|c|}{$\begin{array}{c}\text { Gauge station } \\
\text { Dęblin }\end{array}$} & \multicolumn{2}{|c|}{$\begin{array}{l}\text { Gauge station } \\
\text { Puławy Azoty }\end{array}$} & \multicolumn{2}{|c|}{$\begin{array}{c}\text { Gauge station } \\
\text { Annopol }\end{array}$} \\
\hline & & $\begin{array}{l}\text { water level } \\
(\mathrm{cm})\end{array}$ & $\begin{array}{c}\text { discharge } \\
\left(\mathrm{m}^{3} / \mathrm{s}\right)\end{array}$ & $\begin{array}{c}\text { water level } \\
(\mathrm{cm})\end{array}$ & $\begin{array}{c}\text { discharge } \\
\left(\mathrm{m}^{3} / \mathrm{s}\right)\end{array}$ & $\begin{array}{l}\text { water level } \\
(\mathrm{cm})\end{array}$ & $\begin{array}{c}\text { discharge } \\
\left(\mathrm{m}^{3} / \mathrm{s}\right)\end{array}$ \\
\hline \multicolumn{2}{|l|}{ 03.09.2016 } & 147 & 214 & 122 & 208 & - & - \\
\hline \multicolumn{2}{|l|}{ 04.09.2016 } & 144 & 204 & 117 & 196 & - & - \\
\hline \multicolumn{2}{|l|}{05.09 .2016} & - & - & - & - & 204 & 192 \\
\hline \multirow{6}{*}{$\begin{array}{l}\text { Characteristic } \\
\text { water levels } \\
\text { and discharges } \\
\text { in 1958-2010 }\end{array}$} & NNW & 126 & - & 96 & - & 162 & - \\
\hline & SSW & 232 & - & 244 & - & 345 & - \\
\hline & WWW & 728 & - & 751 & & 782 & - \\
\hline & NNQ & - & 114 & - & 98 & - & 92 \\
\hline & SSQ & - & 518 & - & 465 & - & 449 \\
\hline & WWQ & - & 5500 & - & 6460 & - & 6200 \\
\hline
\end{tabular}

NNW - multiyear minimum water level; SSW - multiyear average water level; WWW - multiyear maximum water level; NNQ - multiyear minimum discharge; SSQ - multiyear average discharge; WWQ - multiyear maximum discharge. 
The direct effect of the echo-sounding surveys was the construction of river-channel bathymetric maps. Interpolation of the point depth measurements was made with the Surfer 10 software using the kriging method. In selected zones, where the depth measurements were not feasible using the echo sounder due to insufficient channel depth, the depth was determined "manually". The bathymetric maps in the form of vector information layers were entered into the GIS database for joint analysis with remote sensing materials. The database was also supplemented with the results of geological drilling and sounding of the river channel, and with the results of mapping surveys of bedforms. All in-house work, excluding interpolation of results of hydrographic measurements, was performed in the GIS database using ESRI Inc. ArcGIS 10.2 software.

\section{RESULTS}

\section{Course of the main river current (channel depth)}

Comparison of the phototonic differences of the aerial images with the bathymetric maps allowed separating different depth zones and determining the course of the main current in the river channel. The cardinal indicator of the direction of minor currents beyond the main river flow was the direction of progradation of depositional bedforms, which is recognizable in the images. Figure 3 shows a compari-

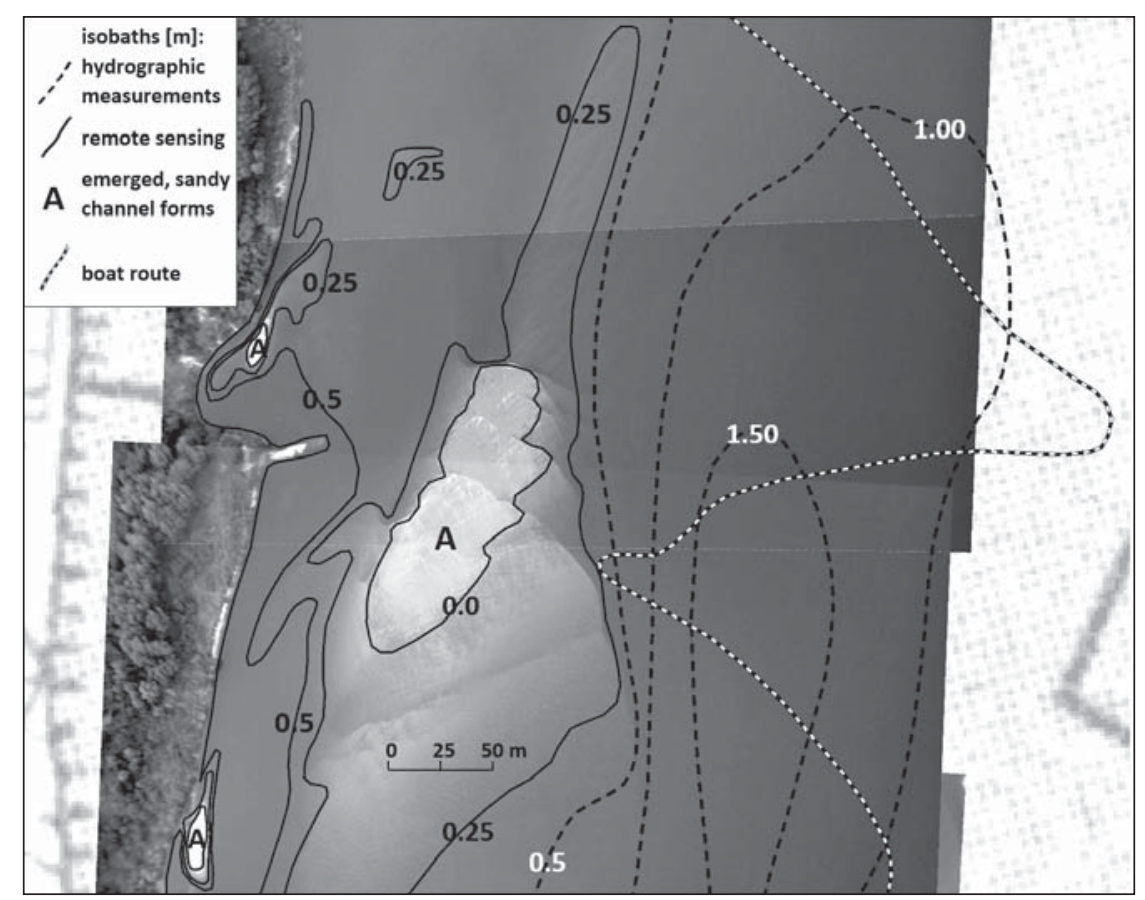

FIGURE 3. Bathymetric chart that resulted from hydrographic measurements and remote sensing works in the background of photo image of Vistula channel in $\mathrm{km} 335.5$ 
son of an aerial image with a bathymetric map of the main flow zone, acquired from echo-sounding surveys. As we can see, the isobath pattern can be extrapolated to the remaining, inaccessible part of the river channel, based on the phototonic differences of the image. This hypothesis was confirmed during the point measurements that were carried out during mapping of the channel bottom. The assessment of the channel depth based on aerial imagery becomes inaccurate if the depth is greater than $2.5-3.0 \mathrm{~m}$.

\section{Distribution of depositional zones and the dynamics of sedimentation}

The aerial images have revealed the presence of bedforms that allow for the identification of depositional zones of different dynamics. Zones of rapid decrease of energy flow are the areas of deltaic deposition (Gradziński 1973, Figs 4, 5). Typically, narrow linguoid strands of sand appear against the background of the dark photophone of deeper zones. They usually occur at the outlets of differently sized chute channels. The characteristics of such zones are significant changes in flow directions, as evidenced by the variability in the direction of progradation of bedforms.

The structure and texture of the depositional bedforms allow for the identification of a number of sedimentary structures within them: megaripples, sand waves, plane bed zones (Zieliński 1998, Figs 4,5$)$. They are indicative of water flow conditions and the associated sedimentation dynamics. The variability in the morphology of bars also allows the identification of proximal zones where

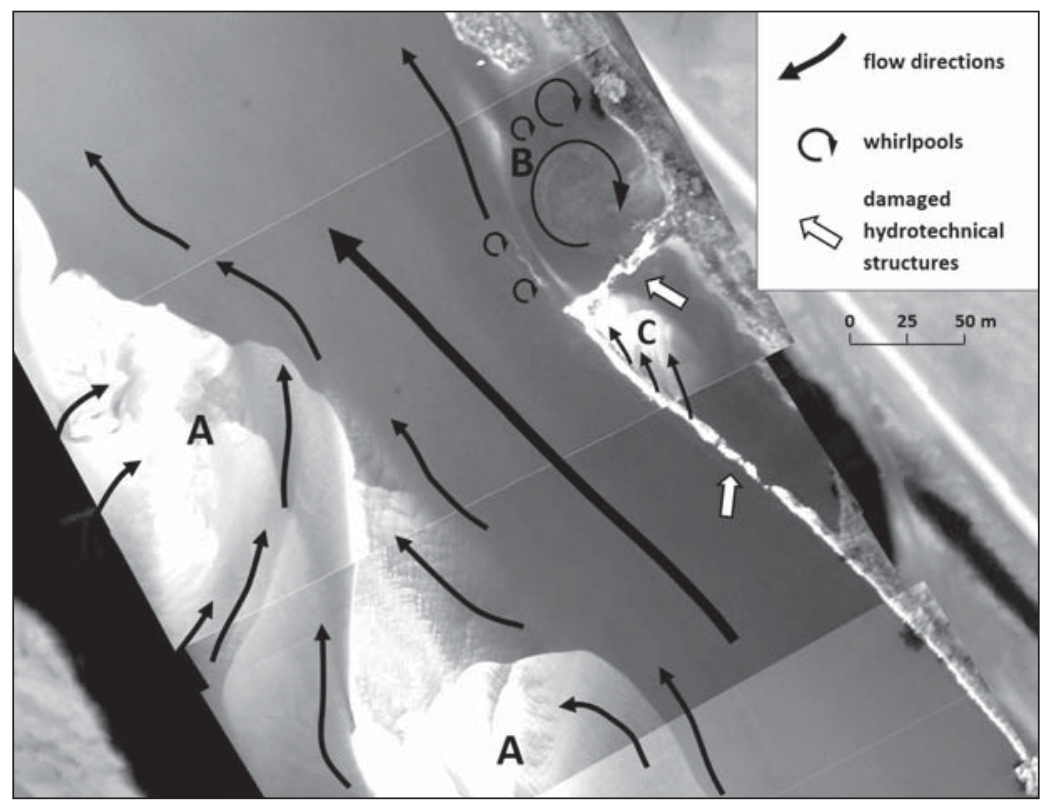

FIGURE 4. Photo sketch of Vistula channel in km 330+700 - 331: A - delta-like deposition zone, $\mathrm{B}$ - evorsion zone, $\mathrm{C}$ - alluvia fan-like depositional zone 
the sands are more compact, as well as distal zones dominated by loose sands.

\section{The phenomenon of evorsion}

The analysed aerial images show very clearly the areas of turbulence and whirlpool erosion (evorsion). Individual evorsion hollows can be identified based on the characteristic circular streaks of a suspension of fine mineral particles and organic matter. The central part of an evorsion hollow typically shows a dark phototon. Evorsion zones recorded during the surveys consist of one or several whirls up to $45 \mathrm{~m}$ in diameter and/or a few minor whirls (Figs 4, 5). The largest forms are mostly surrounded by a narrow semi-circular zone of sandy deposition. Evorsion hollows are features within which the river channel reaches its greatest depth. Under conditions of low water levels (Table) in the Solec section, they are up to $3.5 \mathrm{~m}$ deep, and up to $5 \mathrm{~m}$ in the Gołąb section. Outside of the major whirlpools, zones of minor turbulence are also recognizable within the channel. They occur in the vicinity of deltaic deposition zones. In the analysed sections, the occurrence of evorsion zones is associated primarily with the effects of river engineering structures.

\section{The effect of unimpaired, damaged and buried river engineering structures}

The effect of hydrotechnical structures (for river engineering) is best manifested by both the concentration of the main river current and the development of evorsion zones. They usually form near river groynes (Figs 4, 5).

The presence of remains of damaged engineering structures in the river chan-

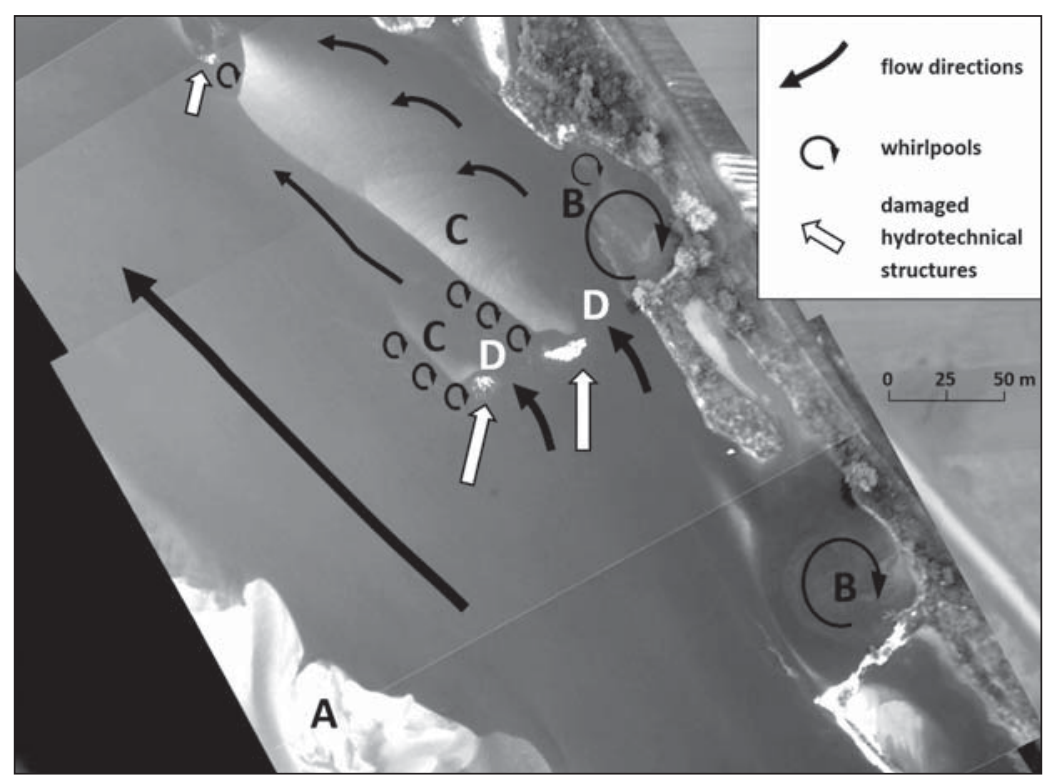

FIGURE 5. Photo sketch of Vistula channel in km 330+700 - 331: A - delta-like depositional zone, $\mathrm{B}$ - evorsion zone, C - sandy bars created "in the shadow" of the hydrotechnical structure remains, $\mathrm{D}$ - zone of concentrated erosion between remains of the hydrotechnical structure 
nel entails its morphodynamic diversity. In the downstream sides of the river groynes (or their remains) cut off from the river banks there are elongated bars often separated by zones of intense erosion (marked by a significantly darker phototone) - Figure 5.

Distinct zones of deposition and erosion also develop in places where even a small part of a damaged hydraulic structure is visible from below the alluvial layer (Fig. 5). The effect of such structures on the channel morphodynamics is observed mainly during massive water flows. The images taken during low water levels clearly reveal their influence on the differentiation of relief and habitat conditions within larger depositional forms. Buried longitudinal dams forming the banks of the presentday river channel are commonly accompanied by deeper water zones. In such zones, there are also elongated series of whirlpools, running parallel to the river banks. Their presence in the aerial images is evidenced by the slurries of matter transported in suspension (Fig. 5).

\section{Zones of groundwater influx to the river channel}

The low water level in the channel during the surveys facilitated identification of variability in hydraulic conductivity of deposits composing the river banks. This variability is based on different lithologies of flood deposits, and on the presence of scours associated with the dynamic flow of flood waters (Falkowski

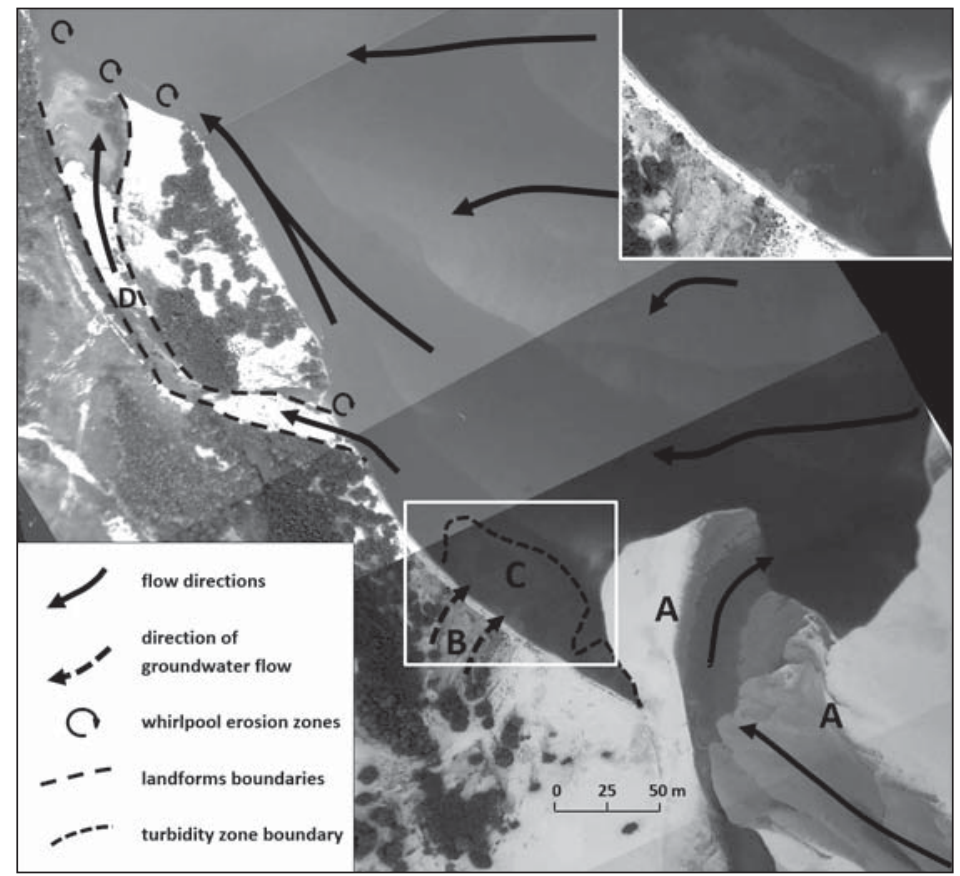

FIGURE 6. Photo sketch of Vistula channel in km 388 - 388+600: A - delta-like depositional zone, $\mathrm{B}$ - zone of concentrated groundwater flow, $\mathrm{C}$ - zone of water turbidity, D - the chute inactive in low water state 
and Ostrowski 2015, Bujakowski and Falkowski 2016). Zones of concentrated groundwater influx to the channel (associated with such scours) are marked in the aerial images by a distinct difference in water turbidity (Fig. 6). The floodplain surface often bears traces of erosion of flood flows in such zones.

\section{DISCUSSION}

A debris-laden braided river, like the present-day middle Vistula, is characterised by high variability and dynamics of processes occurring within its channel. The channel zone relief is constrained by flow conditions not only during floods, but also during prevailing low and medium water levels. However, even then, we observe migration of large-scale channel mesoforms as well as the washing out of previously formed bars, which is usually associated with a change in the flow pattern. The observed changes concern not only the emergent river bedforms, but also the morphology (depth) of the channel bottom. Such processes have been observed many times in different sections of the middle Vistula river (Falkowski 2006, Falkowski and Ostrowski 2015).

Precise imaging of the bathymetry or hypsometry of a braided-river channel based on standardized studies (conducted along designated sections, or spatially using echo sounders integrated with a GNSS receiver) is very difficult. In the case of large rivers that are overloaded with debris, their channels are often characterised by a considerable width and high variability of the relief and riverbed lithology. Significant portions of the channel are inaccessible to hydro- graphic devices during low or even medium water levels due to the very small depth range. In such cases, bathymetric surveys can be regarded as complementary to aerial images taken at the same time. The joint analysis of these two types of geospatial data permits compiling bathymetric maps covering the entire channel zone, and not only its accessible sections.

The diversity of forms identified in the aerial images and the features (sedimentation structures) on their surface testify to a great diversity of environments and processes occurring in the particular sections of the Vistula river channel. Detailed analysis of low-altitude aerial images allows the identification of areas particularly vulnerable to intense erosion and sedimentation. The spatial relationships between the visualised forms are also a valuable source of information. They are a record of the course of river channel processes and can be helpful in predicting the direction of further evolution of the relief (morphogenesis) of the channel.

The analysis of the aerial images has proved the complexity of the impact of hydraulic structures that are in different technical conditions on the character of channel processes. Damaged hydraulic structures, and especially their fragments cut off from the river banks, are responsible for the great morphodynamic diversity of such zones. The remains of such structures affect variably the channel processes as the flow characteristics change.

The spatial resolution of the images and the variability of the remote sensing features (structure, texture, phototone) have allowed not only the identification of forms composing the channel zone, but also, which deserves special atten- 
tion, for the direct recording of the channel processes.

\section{CONCLUSIONS}

The analysis of photographic mosaics assembled based on low-altitude aerial images has allowed the identification and determination of both a number of channel features in the middle Vistula river and the processes within the river channel.

The low-altitude aerial images were taken with a non-metric camera. They have allowed the identification of different depth zones in the Vistula river channel. The channel depth assessment based on such remote sensing data is possible for a depth of 2.5-3.0 m. This assessment will probably not be possible during raised water levels due to high water turbidity.

The surveys have shown that low-altitude aerial images, even in the instance of less advanced remote sensing sensors, can be useful for assessing the morphodynamics of channels of major debris-laden rivers. The results of the remote sensing surveys, however, should be supplemented and verified by observations carried out by means of classical (hydrographic, geological or geomorphological) methods.

\section{REFERENCES}

BAKUŁAK., OSTROWSKI W. 2012: Zastosowanie cyfrowej kamery niemetrycznej w fotogrametrii lotniczej na wybranych przykładach. Arch. Fotogr., Kartogr. Teledet. 24, 11-20 [in Polish].

BUJAKOWSKI F., FALKOWSKI T. 2016: Modelowanie filtracji $\mathrm{w}$ warstwie aluwialnej w warunkach wysokich gradi- entów hydraulicznych spowodowanych wezbraniem. In: St. Witczak, A. Żurek (Eds), Praktyczne metody modelowania przepywu wód podziemnych. AGH, Kraków, 11-22.

FALKOWSKI E. 1971: Historia i prognoza rozwoju układu koryta wybranych odcinków rzek nizinnych Polski. Biul. Geol. 12, 5-121 [in Polish].

FALKOWSKI T. 2006: Naturalne czynniki stabilizujące wybrane odcinki strefy korytowej Wisły środkowej. Wydawnictwo SGGW, Warszawa [in Polish].

FALKOWSKI T., OSTROWSKI P. 2015: Wykorzystanie metod geoinformacyjnych w badaniach morfodynamiki koryta Wisły w Warszawie. Przegl. Geol. 63, 3, 186-194 [in Polish].

FEURER D., BAILLY J.S., PUECH C., Le COARER Y., VIAU A. 2008: Very high resolution mapping of river immersed topography by remote sensing. Prog. Phys. Geogr. 32, 4, 403-419.

GRADZIŃSKI R. 1973: Wyróżnianie i klasyfikacja kopalnych osadów rzecznych. Post. Nauk Geol. 5, 57-112.

KACZYŃSKI R., EWIAK I. 2006: Wysokorozdzielcze zobrazowania satelitarne a zdjęcia lotnicze. Geodezja 12, 2/1 [in Polish].

KOZARSKI S., ROTNICKI K. 1977: Valley floors and changes of river channel patterns in the North Polish Plain during the Late Wurm and Holocene. Quaestiones Geographicae 4, 51-93.

KURCZYNSKI Z. 1999: Zmierzch tradycyjnej kamery lotniczej. Lotnicze kamery cyfrowe - stan obecny i perspektywy. Geodeta 11 (54) [in Polish].

OSTROWSKI P., FALKOWSKI T. 2016: Zastosowanie wysokorozdzielczych wielospektralnych zdjęć satelitarnych (VHR) do identyfikacji wybranych form rzeźby równi zalewowej. Przegl. Geol. 64, 12, 1040-1047 [in Polish].

PERZ-OSOWSKA M., BUTLEWSKI K., MARCHWICKI R., PUCHALSKI W., SZKUDLARZ H. 2011: The Flying Laboratory - an autonomous research and 
observation platform. Pol. J. Environ. Stud. 20, 5A 123-125.

POŻARYSKI WŁ., MARUSZCZAK H., LINDNER L. 1994: Chronostratygrafia osadów plejstoceńskich i rozwój doliny Wisły środkowej ze szczególnym uwzględnieniem przełomu przez wyżyny południowopolskie. Pr. Państ. Inst. Geol. 147, 57 [in Polish].

RZGW Warszawa 2017: Charakterystyka rzek oraz ocena ich potrzeb. https:// warszawa.rzgw.gov.pl/_data/assets/ pdf_file/0017/6290/Charakterystykarzek-oraz-ocena-ich-potrzeb.pdf [accessed 20.04.2017] [in Polish].

SZKUDLARZ H. 2014a: AFIT Flying Laboratory. Pol. Def. Ind. 1 (36), 26-29.

SZKUDLARZ H. 2014b: Uniwersalne stanowisko montażowe dla aparatury badawczej do zastosowania na podwieszeniach samolotu SONEX LL (Latające Laboratorium). ITWL, Warszawa [in Polish].

STARKEL L. 2001: Historia doliny Wisły od ostatniego zlodowacenia do dziś. Monografie PAN IGiPZ [in Polish].

SZUMAŃSKI A. 1986: Postglacjalna ewolucja i mechanizm transformacji dna doliny Dolnego Sanu. Zesz. Nauk. AGH Geologia 12, 1, 5-92 [in Polish].

THORNDYCRAFT V.R., BENITO G., GREGORY K.J. 2008: Fluvial geomorphology: A perspective on current status and methods. Geomorphology 98, 2-12.

WITEK M., JEZIORSKA J., NIEDZIELSKI T. 2013: Możliwości wykorzystania bezzałogowej fotogrametrii lotniczej do identyfikacji przekształceń antropogenicznych w korytach rzecznych. Landform Analysis 24, 115-126 [in Polish].

ŻARSKI M. 1993: Objaśnienia do Szczegółowej mapy geologicznej Polski w skali 1:50 000, arkusz Dęblin. Państwowy Instytut Geologiczny.

ZIELIŃSKI T. 1998: Litofacjalna identyfikacja osadów rzecznych. In: F. Mycialska-Dowgiałło (Ed.), Struktury sedymen- tacyjne i postsedymentacyjne w osadach czwartorzędowych i ich wartość interpretacyjna. Wydział Geografii i Studiów Regionalnych UW, Warszawa, 193-260.

Streszczenie: Przydatność zdjęć lotniczych wykonywanych z niskiego pułapu dla oceny morfodynamiki koryta rzeki nizinnej. Artykuł przedstawia przykłady zastosowania zdjęć koryta współczesnej rzeki pozyskanych z niskiego pułapu przy użyciu lekkiego samolotu. Zdjęcia wykonywano w dwóch odcinkach koryta Wisły: w obrębie Małopolskiego Przełomu oraz w okolicach Dęblina i Gołębia. Równolegle z lotami badawczymi prowadzono naziemne badania strefy korytowej, takie jak: echosondaż koryta i kartowanie geologiczne. Porównanie wyników badań lotniczych i naziemnych wykazało dużą czytelność obrazu uzyskanych zdjęć, umożliwiającą precyzyjną identyfikację faktów świadczących o określonym przebiegu procesów korytowych. Zdjęcia lotnicze wykonywane $\mathrm{z}$ zastosowaniem lekkich samolotów, ze względu na małe wymagania logistyczne, mogą wydatnie zwiększyć precyzję badań geologicznych i geomorfologicznych stref korytowych rzek na Niżu Polskim.

\section{MS received June 2017}

\section{Authors' addresses:}

Piotr Ostrowski, Tomasz Falkowski

Katedra Geoinżynierii

Wydział Budownictwa i Inżynierii Środowiska SGGW

ul. Nowoursynowska 166, 02-787 Warszawa

Poland

e-mail: piotr_ostrowski@sggw.pl tomasz_falkowski@sggw.pl

Dariusz Karczmarz, Przemysław Mądrzycki, Henryk Szkudlarz

Zakład Systemów Szkoleniowych

Instytut Techniczny Wojsk Lotniczych

ul. Księcia Bolesława 6, 01-494 Warszawa

Poland

e-mail: dariusz.karczmarz@itwl.pl przemyslaw.madrzycki@itwl.pl henryk.szkudlarz@itwl.pl 